\title{
Erratum
}

Ann Rehabil Med 2016;40(6):1151

pISSN: 2234-0645 • eISSN: 2234-0653

https://doi.org/10.5535/arm.2016.40.6.1151

\section{An Erratum to Correct Typographical Errors}

After the publication of this work [1], we noticed that the ORCID of the second author (Jin-Hong Kim) was displayed incorrectly. The corrected ORCID is shown below.

Jin-Hong Kim (http://orcid.org/0000-0003-1871-8400)

After the publication of this work [2], we noticed that the fourth author's name 'Dong-Joo Kim' was incorrectly listed as 'Dong-Ju Kim'.

We sincerely apologized to the readers.

\section{References}

1. Choi CM, Kim JH, Lee JK, Lee BY, Kee HS, Jung KI, et al. Effects of repetitive transcranial magnetic stimulation over trunk motor spot on balance function in stroke patients. Ann Rehabil Med 2016;40:826-34.

2. Lee KY, Han JY, Kim JH, Kim DJ, Choi IS. Physiological responses during the lower body positive pressure supported treadmill test. Ann Rehabil Med 2016;40:915-23.

@ This is an open-access article distributed under the terms of the Creative Commons Attribution Non-Commercial License (http://creativecommons.org/ licenses/by-nc/4.0) which permits unrestricted noncommercial use, distribution, and reproduction in any medium, provided the original work is properly cited. Copyright $\odot 2016$ by Korean Academy of Rehabilitation Medicine 